JOANNA FURMAŃSKA (D) orcid.org/0000-0002-0482-3296

Instytut Psychologii, Uniwersytet Szczeciński Institute of Psychology, University of Szczecin e-mail: furmanska-joanna@wp.pl

TERESA RZEPA ID orcid.org/0000-0002-2128-8416

Uniwersytet SWPS, Wydział Zamiejscowy, Poznań University of Social Sciences and Humanities, Department of Poznan

ŁUCJA DOMAŃSKA (D) orcid.org/0000-0002-2064-8053

Instytut Psychologii, Uniwersytet Marii Curie-Skłodowskiej, Lublin Institute of Psychology, Maria Curie-Sklodowska University

DOROTA KOZIARSKA (D) orcid.org/0000-0003-15 48-184X

Klinika Neurologii, Pomorski Uniwersytet Medyczny, Szczecin Department of Neurology, Pomeranian Medical University in Szczecin

\title{
Okres życia a znaczenie nadawane chorobie na przykładzie badań chorych na stwardnienie rozsiane
}

\author{
The Period of Life and Meaning Attributed to Disease \\ on the Example of Multiple Sclerosis
}

\begin{abstract}
The main aim of the study was to analyse the cross-reference between individualised means of experiencing a disease (assessment of its significance), as determined by the level of disability and selected psychosocial factors, and the period of life of patients with Multiple Sclerosis. The following were used in the study: Disease-Related Appraisals Scale, Generalized Self-Efficacy Scale, Expanded Disability Status Scale EDSS and the original questionnaire on sociodemographic characteristics. The study showed that patients with a chronic disease show a statistically significant differentiation in terms of the meaning attributed to disease as the benefit and obstacle. Moreover, the age of the patients under study also shows differentiation with respect to the significance of particular factors for the means of experiencing the disease (assessment of its significance). The findings obtained in the course of the present study indicate the importance of unique and typical determinants of functioning of patients with Multiple Sclerosis, as well as point to the significance of the factor of age which should be taken into account in the work of interdisciplinary teams providing care to this population of patients.
\end{abstract}

Keywords: early adulthood, middle adulthood, disease-related appraisal, multiple sclerosis

Słowa kluczowe: wczesna dorosłość, średnia dorosłość, ocena własnej choroby, stwardnienie rozsiane 


\section{WPROWADZENIE}

Stresującą sytuację życiową spowodowaną przewlekłą chorobą określa się jako trudną poznawczo, emocjonalnie i społecznie, wymagającą od chorego i jego otoczenia wypracowania nowych strategii radzenia sobie ze stresem, co niejednokrotnie przekracza możliwości adaptacyjne osób uwikłanych w tę sytuację (Leventhal, Idler, Leventhal, 1999; Strelau, 1996; Watkins, Connell, Fitzgerald, Klem, Hickey, Ingersoll-Dayton, 2000; Ziarko, 2014). Choroba obniża jakość życia, a indywidualna ocena pogorszenia własnego stanu zdrowia powoduje wzmocnienie efektu wywołującego stres. Zazwyczaj obserwuje się tu wzajemne zależności, gdyż z jednej strony trudne i stresogenne sytuacje mogą przyczyniać się do powstawania chorób, a z drugiej - charakter choroby i wynikające z niej konsekwencje mogą stanowić odnawialne źródło stresu (Lazarus, Folkman, 1984; Heszen, Sęk, 2007). Stąd też w kontekście indywidualnych zmagań z chorobą przewlekłą ważną rolę odgrywa możliwość satysfakcjonującego funkcjonowania w rodzinie, zawodzie i otoczeniu społecznym, a tym samym - swobodnej realizacji zadań rozwojowych typowych dla danego etapu życia.

Spośród licznych propozycji periodyzacji życia ludzkiego na szczególną uwagę zasługuje koncepcja Davida Levinsona i współpracowników (1978, 1986, za: Kielar-Turska, 2000; Brzezińska, 2005; Brzezińska, Trempała, 2000; Harwas-Napierała, Trempała, 2007), która stanowi kompleksowe ujęcie rozwoju człowieka, rozpatrując zmiany biologiczne, społeczne i psychiczne, tak istotne w ocenie funkcjonowania człowieka w chorobie. W biegu ludzkiego życia Levinson wyodrębnił cztery sekwencje (ery) i trzy okresy przejściowe. Każda sekwencja trwa około 25 lat (gdyż ery zachodzą na siebie) i w każdej z nich człowiek tworzy podstawowy w danym okresie wzorzec aktywności i relacji z otoczeniem. Sekwencja ,wczesna dorosłość” trwa od 17. do ok. 45. roku życia. Na ten okres przypada szczyt rozwoju biologicznego i psychicznego oraz realizacja tak ważnych celów i zadań rozwojowych, jak założenie rodziny, zdobycie zawodu czy zbudowanie własnej pozycji społecznej. Młody dorosły dokonuje więc wyborów, które będą decydować o kształcie jego dalszego życia i które mogą być źródłem zarówno wewnętrznej satysfakcji, jak i druzgocącego stresu. Warto dodać, że również Steven K. Baum i Robert B. Stewart Jr. (1990) stwierdzają, iż większość ważnych wydarzeń życiowych ma miejsce do 43. roku życia.

W świetle koncepcji Levinsona osoba w wieku około 45 lat znajduje się w okresie przejścia do średniej dorosłości, które może być łagodne bądź obciążone niepokojem związanym z zaburzeniami samooceny czy poczucia sensu życia. Jednym z zadań rozwojowych jest tu konieczność zmierzenia się z jungowską indywiduacją, wymagającą refleksyjności i rozwagi oraz zdystansowania się do wewnętrznych konfliktów i zewnętrznych wymagań. Wiek średni wyznacza początek fazy stabilizacji, umacniania wypracowanej struktury życia, a do zadań rozwojowych tego stadium należą: przyjmowanie odpowiedzialności za sprawy społeczne, wspomaganie dzieci w stawaniu się odpowiedzialnymi dorosłymi, utrzymywanie satysfakcjonującej kariery zawodowej, opieka nad starzejącymi się rodzicami oraz pogodzenie się z oznakami własnego starzenia (Brzezińska, 2005; Brzezińska, Trempała, 2000; Harwas-Napierała, Trempała, 2007; Levinson, 1978; 1986, za: Kielar-Turska, 2000).

Pojawienie się przewlekłej choroby w opisanych okresach rozwoju, powiązanych z kluczowymi wydarzeniami życiowymi, stanowi wyjątkowo negatywne doświadczenie. Dotychczasowe życie osób chorych ulega wtedy radykalnej zmianie w wymiarze osobistym, rodzinnym, zawodowym i społecznym. Takie konsekwencje powoduje (m.in.) stwardnienie rozsiane, którego pierwsze objawy pojawiają się przeważnie między 20. a 40. rokiem życia, a przewlekły charakter tej choroby rzutuje na kolejne fazy życiowe.

Stwardnienie rozsiane (sclerosis multiplex, $\mathrm{SM}$ ) jest przewlekłą chorobą demielinizacyjną ośrodkowego układu nerwowego, o niejasnej etiologii (Wender, Liberski, 2013). W klasyfikacji klinicznej wyróżnia się następujące postacie SM: rzutowo-remisyjna (SMRR), wtórnie postępująca (SMSP), pierwotnie postępująca (SMPP) i łagodna (SMPR). W zdecydowanej większości (ok. 80\%) choroba zaczyna się od postaci SMRR, która charakteryzuje się występowaniem ciągle 
nowych objawów neurologicznych bądź zaostrzeń objawów już istniejących (rzutów) (Maciejak, Wawrzyniak, 2013; Selmaj, 2005). Przebieg kliniczny stwardnienia rozsianego jest zróżnicowany. Objawy początkowe pojawiają się nagle, ale znikają w ciągu godzin, dni bądź tygodni. Do najczęstszych objawów tego typu należą: zaburzenia czucia w kończynach $(31 \%)$, zaburzenia widzenia bądź osłabienie ostrości wzroku $(16 \%)$, narastający niedowład (9\%), podwójne widzenie $(7 \%)$, zaburzenia chodu $(5 \%)$, ostre zaburzenia ruchowe (4\%), zaburzenia czucia w obrębie twarzy i zaburzenia równowagi (po $3 \%$ ), zawroty głowy ( $2 \%)$, a także objawy dotyczące pęcherza moczowego, odbytnicy, nerwobóle, ostre zapalenie poprzeczne rdzenia kręgowego (po 1\%) (Maciejak, Wawrzyniak, 2013).

Ważnym aspektem analizowanej jednostki chorobowej jest to, iż dotyka ona osoby znajdujące się na ważnym etapie rozwoju osobistego, wkraczające dopiero w życie zawodowe i rodzinne. Jednak z czasem przewlekły i postępujący charakter choroby odciska swe piętno na wszystkich obszarach funkcjonowania biopsychospołecznego. Wartościowe wydaje się więc skupienie na zindywidualizowanych sposobach doświadczania choroby w kontekście okresu życia pacjentów.

\section{CEL PRACY I HIPOTEZY BADAWCZE}

Ze względu na złożony obraz SM w przypadku oceny stanu pacjenta należy brać pod uwagę nie tylko czynniki obiektywne, związane $\mathrm{z}$ diagnozą medyczną, lecz także czynniki natury psychospołecznej, m.in. spostrzeganie i ocenę doświadczanych dolegliwości, stosunek do choroby i procesu leczenia, satysfakcję z życia rodzinnego i zawodowego oraz ze społecznego i instytucjonalnego wsparcia. Głównym celem przeprowadzonego badania stało się więc odniesienie zindywidualizowanych sposobów doświadczania choroby, czyli oceny jej znaczenia (zmienna zależna), uwarunkowanych poziomem niepełnosprawności i wybranymi czynnikami psychospołecznymi, takimi jak płeć, stan cywilny, wykształcenie, poczucie własnej skuteczności (zmienne niezależne), do wieku pacjentów (zmienna kontrolowana). Badania wskazują, że wiek stanowi jeden z czynników różnicujących ocenę znaczenia własnej choroby (Janowski, 2006). Osoby młode, w średnim wieku i starsze odmiennie postrzegają objawy choroby, a także przejawiają zindywidualizowane postawy wobec niej (Tobiasz-Adamczyk, Zapała, Zawisza, Bronicki, 2007).

Sformułowano następujące hipotezy:

- H1. Pacjenci z dwóch wyodrębnionych przedziałów wiekowych różnią się sposobem poznawczego ustosunkowania do swojej choroby.

- H2. Istnieje związek między wybranymi czynnikami psychospołecznymi a oceną znaczenia choroby w zależności od wieku pacjentów.

\section{METODA}

Do grupy badanych wybrano 118 pacjentów z rzutowo-remisyjną postacia stwardnienia rozsianego (SMRR), leczących się w Przyklinicznej Poradni Stwardnienia Rozsianego przy Samodzielnym Publicznym Szpitalu Klinicznym Pomorskiego Uniwersytetu Medycznego w Szczecinie, członków Polskiego Towarzystwa Stwardnienia Rozsianego w Szczecinie oraz uczestników Centrum Rehabilitacji dla Osób Chorych na Stwardnienie Rozsiane w Bornym Sulinowie. Projekt otrzymał zgodę Komisji Bioetycznej Instytutu Psychologii Uniwersytetu Szczecińskiego (KB 1/2016).

Jako że SM pojawia się najczęściej w okresie dynamicznego rozwoju osobistego, rodzinnego i zawodowego, zbadano chorych z wczesnej i średniej dorosłości, zgodnie z podziałem zaproponowanym przez Levinsona, a więc 59 pacjentów w wieku do 45 lat (25-45. r.ż.; $M=$ 36.37; $S D=5.988)$ oraz $59-$ od 46. roku życia (46-66 r.ż.; $M=55.39 ; S D=6.060)$ (tabela 1).

Kobiety stanowiły $68,6 \%$ badanych (stosunek 2 : 1 , zgodnie ze specyfiką rozkładu płci wśród chorujących na SMRR). W związku małżeńskim lub partnerskim pozostawało $88.1 \%$ chorych w wieku do 45 . r.ż. i $76.3 \%$ chorych w wieku powyżej 46 lat. Większość badanych posiadała wykształcenie średnie bądź wyższe. Niepełnosprawność ogółu pacjentów 
Tabela 1. Rozkład zmiennych socjodemograficznych w dwóch grupach wiekowych pacjentów z rozpoznaniem stwardnienia rozsianego (SMRR)

\begin{tabular}{|c|c|c|c|c|}
\hline \multirow{2}{*}{\multicolumn{2}{|c|}{ Zmienne }} & do 45. r.ż. $N=59$ & od 46. r.ż. $N=59$ & \\
\hline & & $\%$ & $\%$ & $\mathrm{p}$ \\
\hline \multirow{2}{*}{ płeć } & kobiety & 69.5 & 67.8 & \multirow{2}{*}{$\begin{array}{l}\chi^{2}=.039 \\
\mathrm{df}=1 ; \mathrm{p}>.05\end{array}$} \\
\hline & mężczyźni & 30.5 & 32.2 & \\
\hline \multirow{2}{*}{ stan cywilny } & samotni & 11.9 & 23.7 & \multirow{2}{*}{$\begin{array}{l}\chi^{2}=2.838 \\
\mathrm{df}=1 ; \mathrm{p}>.05\end{array}$} \\
\hline & w związku & 88.1 & 76.3 & \\
\hline \multirow{4}{*}{ wykształcenie } & zawodowe & 1.7 & 32.2 & \multirow{4}{*}{$\begin{array}{l}\chi^{2}=23.533 \\
\mathrm{df}=3 ; \mathrm{p}<.001 * * *\end{array}$} \\
\hline & średnie & 50.8 & 40.7 & \\
\hline & licencjackie & 0 & 3.4 & \\
\hline & wyższe & 47.5 & 23.7 & \\
\hline
\end{tabular}

$* * * \mathrm{p}<.001$

Źródło: badanie własne.

z SMRR mieściła się w przedziale od 0 do 6.5 pkt (EDSS), przy średniej arytmetycznej $M=$ 2.864 pkt $(S D=1.8682)$, przy czym wśród osób w wieku do 45 lat odnotowano niższe nasilenie niepełnosprawności niż wśród osób starszych $(p$ $<.001$; odpowiednio: 0-6.5 pkt; $M=1.720, S D$ $=1.1754 ; 0-6.5 \mathrm{pkt} ; M=4.008, S D=1.7308$ ).

Do badania zastosowano następujące narzędzia: Skalę Oceny Własnej Choroby (Janowski, Steuden, Kuryłowicz, Nieśpiałowska-Steuden, 2009), Skalę Uogólnionej Własnej Skuteczności (Schwarzer, Jerusalem, Juczyński, 1998), Rozszerzoną Skalę Niewydolności Ruchowej EDSS (Expanded Disability Status Scale, Kurtzke, 1983) oraz autorski kwestionariusz, który posłużył do zebrania informacji socjodemograficznych.

Skalę Oceny Własnej Choroby wykorzystano w celu zbadania subiektywnych znaczeń nadawanych własnej chorobie. Skala składa się z 47 twierdzeń i pozwala na ocenę własnej choroby w następujących kategoriach: Zagrożenie (choroba spostrzegana jako wydarzenie zakłócające dotychczasowy stan równowagi i bezpieczeństwa), Korzyść (choroba ujmowana w kategoriach osiągania wtórnych zysków, usprawiedliwienia wobec innych czy zwolnienia z obowiązków), Przeszkoda/Strata (choroba spostrzegana jako ograniczenie i utrudnienie w codziennym funkcjonowaniu), Wyzwanie (choroba spostrzegana jako jedna z sytuacji trudnych, którą przynosi życie i którą za po- mocą dostępnych środków trzeba pokonać), Krzywda (choroba ujmowana w kategoriach losowego wydarzenia, stanowiącego niesprawiedliwość), Wartość (choroba ujmowana jako wyższa wartość: choć niełatwa do przyjęcia, to posiadająca głębszy sens). Ponadto metoda ta zawiera skalę kontrolną Znaczenie, która umożliwia pomiar negatywnego znaczenia przypisywanego własnej chorobie (Janowski i in., 2009). Wskaźnik alfa-Cronbacha dla poszczególnych skal wynosił: zagrożenie - .88; korzyść - .62; przeszkoda - .84; wyzwanie - .62; krzywda .83; wartość - .75; skala kontrolna (negatywne znaczenie nadawane własnej chorobie) - .68.

Skala Uogólnionej Własnej Skuteczności składa się z 10 twierdzeń i mierzy ogólne przekonanie o własnej skuteczności w zakresie radzenia sobie $\mathrm{z}$ trudnymi sytuacjami i przeszkodami oraz pozwala przewidywać intencje i działania w różnych obszarach funkcjonowania, w tym - zachowania zdrowotne (Juczyński, 2001; Schwarzer, 1993). Rzetelność Skali, określona za pomocą wskaźnika $\alpha$-Cronbacha, równała się 0.86 .

Rozszerzona Skala Niewydolności Ruchowej EDSS (Kurtzke, 1983) opiera się na badaniu klinicznym ośrodkowego układu nerwowego, w którym po szczegółowym badaniu neurologicznym $z$ uwzględnieniem funkcji nerwów czaszkowych, czucia, koordynacji, sprawności ruchowej oraz zaburzeń funkcji zwieraczy, poziomu nasilenia zmęczenia i otępienia następuje kategoryzacja dysfunkcji. W ostatecznej 
punktacji dodatkowo uwzględnia się sprawność chodu na dystansie $500 \mathrm{~m}$. Badanie to pozwala na ocenę niepełnosprawności w przedziale od 0 (stan neurologiczny prawidłowy) do 10 punktów. Im wyższa punktacja, tym większe nasilenie niesprawności.

\section{WYNIKI}

W pierwszej kolejności ustalono, że chorzy z SMRR z wyróżnionych grup wieku podobnie oceniają chorobę w kategorii ważnego i negatywnego wydarzenia życiowego (tabela 2).

Tabela 2. Ocena choroby jako negatywnego wydarzenia życiowego dokonana przez osoby chore na SMRR mierzona za pomocą Skali Oceny Własnej Choroby

\begin{tabular}{|l|c|c|c|c|}
\hline & Min teoretyczne/ empiryczne & Max teoretyczne/ empiryczne & M & SD \\
\hline Osoby chore ogółem & $5 / 5$ & $25 / 25$ & 16.73 & 4.614 \\
\hline Osoby chore do 45. r.ż. & 5 & 24 & 16.51 & 4.297 \\
\hline Osoby chore od 46. r.ż. & 5 & 25 & 16.95 & 4.939 \\
\hline
\end{tabular}

Min teoretyczne - minimalny wynik możliwy do uzyskania w wybranej podskali Skali Oceny Własnej Choroby Min empiryczne - minimalny wynik uzyskany przez badanych w wybranej podskali Skali Oceny Własnej Choroby Max teoretyczne - maksymalny wynik możliwy do uzyskania w wybranej podskali Skali Oceny Własnej Choroby Max empiryczne - maksymalny wynik uzyskany przez badanych w wybranej podskali Skali Oceny Własnej Choroby Źródło: badanie własne.

Tabela 3. Ocena znaczenia własnej choroby dokonana przez chorych na SMRR $(\mathrm{N}=118)$ mierzona za pomocą Skali Oceny Własnej Choroby

\begin{tabular}{|c|c|c|c|c|c|c|}
\hline \multirow{5}{*}{ 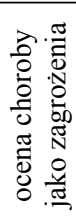 } & & Min teoretyczne/ & Max teoretyczne/ & \multirow[t]{2}{*}{$\mathbf{M}$} & \multirow[t]{2}{*}{ SD } & Istotność \\
\hline & & Min empiryczne & Max empiryczne & & & $\mathbf{p}$ \\
\hline & Osoby chore ogółem & $8 / 8$ & $40 / 40$ & 26.31 & 8.427 & \\
\hline & Osoby chore do 45. r.ż. & 8 & 40 & 25.92 & 8.617 & \\
\hline & Osoby chore od 46. r.ż. & 8 & 40 & 26.69 & 8.288 & \\
\hline \multirow{3}{*}{ 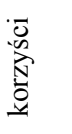 } & Osoby chore ogółem & $7 / 7$ & $35 / 27$ & 15.28 & 4.795 & \\
\hline & Osoby chore do 45. r.ż. & 7 & 23 & 14.07 & 4.362 & \multirow[t]{2}{*}{$* * \mathrm{p}<.01$} \\
\hline & Osoby chore od 46. r.ż. & 7 & 27 & 16.49 & 4.935 & \\
\hline \multirow{3}{*}{ 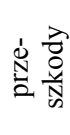 } & Osoby chore ogółem & $8 / 8$ & $40 / 39$ & 22.40 & 7.872 & \\
\hline & Osoby chore do 45. r.ż. & 8 & 35 & 19.80 & 7.367 & \multirow[t]{2}{*}{$* * \mathrm{p}<.01$} \\
\hline & Osoby chore od 46. r.ż. & 8 & 39 & 25.00 & 7.548 & \\
\hline \multirow{3}{*}{$\overbrace{3}^{\frac{1}{3}} \cdot \frac{\pi}{3}$} & Osoby chore ogółem & $6 / 10$ & $30 / 30$ & 22.52 & 4.191 & \\
\hline & Osoby chore do 45. r.ż. & 10 & 30 & 22.19 & 4.257 & \\
\hline & Osoby chore od 46. r.ż. & 13 & 30 & 22.85 & 4.135 & \\
\hline \multirow{3}{*}{ 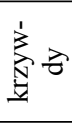 } & Osoby chore ogółem & $7 / 7$ & $35 / 35$ & 17.03 & 6.887 & \\
\hline & Osoby chore do 45. r.ż. & 7 & 34 & 16.80 & 6.392 & \\
\hline & Osoby chore od 46. r.ż. & 7 & 35 & 17.25 & 7.397 & \\
\hline \multirow{3}{*}{ 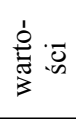 } & Osoby chore ogółem & $6 / 6$ & $30 / 30$ & 16.47 & 5.409 & \\
\hline & Osoby chore do 45. r.ż. & 6 & 29 & 15.90 & 5.044 & \\
\hline & Osoby chore od 46. r.ż. & 6 & 30 & 17.03 & 5.738 & \\
\hline
\end{tabular}

$* * \mathrm{p}<.01$

Min teoretyczne - minimalny wynik możliwy do uzyskania w wybranej podskali Skali Oceny Własnej Choroby Min empiryczne - minimalny wynik uzyskany przez badanych w wybranej podskali Skali Oceny Własnej Choroby Max teoretyczne - maksymalny wynik możliwy do uzyskania w wybranej podskali Skali Oceny Własnej Choroby Max empiryczne - maksymalny wynik uzyskany przez badanych w wybranej podskali Skali Oceny Własnej Choroby Źródło: badanie własne. 
Następnie porównano znaczenie nadawane własnej chorobie przez młodszych i starszych chorych.

Stwierdzono, że przewlekle chorych pacjentów istotnie statystycznie $(\mathrm{p}<.01)$ różnicuje ocena znaczenia choroby jako korzyści oraz przeszkody w taki sposób, że młodsi chorzy w mniejszym stopniu oceniają SM w tych kategoriach.

W dalszej kolejności sprawdzono powiązania między zmiennymi socjodemograficznymi a oceną znaczenia własnej choroby w kontekście wieku pacjentów. W tym celu wykonano wielokrotne analizy regresji z wykorzystaniem metody eliminacji wstecznej. Metoda ta polega na wprowadzeniu do modelu predyktorów ( $\mathrm{tj}$. płci $^{1}$, wykształcenia ${ }^{2}$, stanu cywilnego ${ }^{3}$, niepełnosprawności i poczucia własnej skuteczności), a następnie na eliminowaniu tych spośród nich, których usunięcie nie powoduje istotnego spadku wartości predykcyjnej modelu.

Tabela 4. Ocena znaczenia własnej choroby wśród osób chorych na SMRR w wieku do 45. r.ż. $(\mathrm{N}=59)$ mierzona za pomocą Skali Oceny Własnej Choroby

\begin{tabular}{|c|c|c|c|c|c|c|}
\hline & Predyktory & B & $\begin{array}{c}\text { Bląd } \\
\text { standardowy }\end{array}$ & $\boldsymbol{\beta}$ & Podsumowanie modelu & $\begin{array}{c}\text { Skorygowa- } \\
\text { ne } \mathbf{R}^{2}\end{array}$ \\
\hline \multirow{6}{*}{ 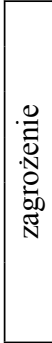 } & stała & 55.442 & 10.485 & & $F(5 ; 53)=2.733 ; p<.05$ & .130 \\
\hline & płeć & 2.619 & 2.339 & .141 & & \\
\hline & stan cywilny & 1.363 & 3.469 & .052 & & \\
\hline & wykształcenie & .835 & 2.271 & .049 & & \\
\hline & \begin{tabular}{|l|}
$\begin{array}{l}\text { poczucie własnej } \\
\text { skuteczności }\end{array}$ \\
\end{tabular} & -.925 & .273 & $-.441^{* *}$ & & \\
\hline & $\begin{array}{l}\text { poziom niepełno- } \\
\text { sprawności }\end{array}$ & -1.791 & .982 & -.244 & & \\
\hline \multirow{6}{*}{$\left|\begin{array}{c}0 \\
0 \\
0 \\
0 \\
0 \\
0 \\
\hdashline\end{array}\right|$} & stała & 18.235 & 5.623 & & $F(5 ; 53)=1.282 ; p>.05$ & .024 \\
\hline & płeć & -.674 & 1.254 & -.072 & & \\
\hline & \begin{tabular}{|l|} 
stan cywilny \\
\end{tabular} & -1.095 & 1.860 & -.082 & & \\
\hline & \begin{tabular}{|l|} 
wykształcenie \\
\end{tabular} & -.813 & 1.218 & -.094 & & \\
\hline & $\begin{array}{l}\text { poczucie własnej } \\
\text { skuteczności }\end{array}$ & -.116 & .146 & -.110 & & \\
\hline & $\begin{array}{l}\text { poziom niepełno- } \\
\text { sprawności }\end{array}$ & .820 & .527 & .221 & & \\
\hline \multirow{6}{*}{ 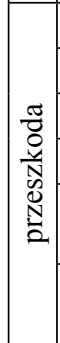 } & stała & 48.165 & 8.473 & & $\mathrm{~F}(5 ; 53)=4.322 ; \mathrm{p}<.01$ & .223 \\
\hline & płeć & .161 & 1.890 & .010 & & \\
\hline & \begin{tabular}{|l|} 
stan cywilny \\
\end{tabular} & -1.499 & 2.803 & -.066 & & \\
\hline & wykształcenie & -1.292 & 1.835 & -.088 & & \\
\hline & \begin{tabular}{|l|}
$\begin{array}{l}\text { poczucie własnej } \\
\text { skuteczności }\end{array}$ \\
\end{tabular} & -.860 & .220 & $-.479 * * *$ & & \\
\hline & $\begin{array}{l}\text { poziom niepełno- } \\
\text { sprawności }\end{array}$ & .694 & .794 & .111 & & \\
\hline \multirow{6}{*}{ 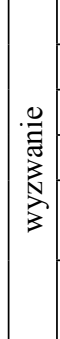 } & stała & 19.669 & 5.773 & & $F(5 ; 53)=.134 ; p>.05$ & .081 \\
\hline & płeć & -.634 & 1.288 & -.069 & & \\
\hline & \begin{tabular}{|l|} 
stan cywilny \\
\end{tabular} & .288 & 1.910 & .022 & & \\
\hline & wykształcenie & .334 & 1.250 & .040 & & \\
\hline & \begin{tabular}{|l|}
$\begin{array}{l}\text { poczucie własnej } \\
\text { skuteczności }\end{array}$ \\
\end{tabular} & .060 & .150 & .058 & & \\
\hline & $\begin{array}{l}\text { poziom niepełno- } \\
\text { sprawności }\end{array}$ & .356 & .541 & .098 & & \\
\hline
\end{tabular}




\begin{tabular}{|c|c|c|c|c|c|c|}
\hline & Predyktory & B & $\begin{array}{c}\text { Bląd } \\
\text { standardowy }\end{array}$ & $\beta$ & Podsumowanie modelu & $\begin{array}{c}\text { Skorygowa- } \\
\text { ne } \mathbf{R}^{2}\end{array}$ \\
\hline \multirow{6}{*}{ 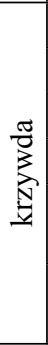 } & stała & 36.768 & 8.053 & & $F(5 ; 53)=1.837 ; p>.05$ & .067 \\
\hline & płeć & .325 & 1.796 & .024 & & \\
\hline & stan cywilny & -2.807 & 2.664 & -.143 & & \\
\hline & wykształcenie & -2.972 & 1.744 & -.234 & & \\
\hline & $\begin{array}{l}\text { poczucie własnej } \\
\text { skuteczności }\end{array}$ & -.494 & .209 & -.317 & & \\
\hline & $\begin{array}{l}\text { poziom niepełno- } \\
\text { sprawności }\end{array}$ & -.220 & .754 & -.040 & & \\
\hline \multirow{6}{*}{$\begin{array}{l}: 0 \\
0 \\
0 \\
0 \\
0 \\
3 \\
3 \\
3\end{array}$} & stała & 13.720 & 6.495 & & $F(5 ; 53)=1.305 ; p>.05$ & .026 \\
\hline & płeć & .081 & 1.449 & .007 & & \\
\hline & stan cywilny & -3.224 & 2.149 & -.209 & & \\
\hline & wykształcenie & -2.691 & 1.406 & -.269 & & \\
\hline & \begin{tabular}{|l|}
$\begin{array}{l}\text { poczucie własnej } \\
\text { skuteczności }\end{array}$ \\
\end{tabular} & .182 & .169 & .148 & & \\
\hline & $\begin{array}{l}\text { poziom niepełno- } \\
\text { sprawności }\end{array}$ & .212 & .608 & .049 & & \\
\hline \multirow{6}{*}{ 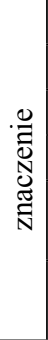 } & stała & 32.858 & 4.825 & & $\mathrm{~F}(5 ; 53)=5.057 ; \mathrm{p}<.01$ & .259 \\
\hline & płeć & 1.817 & 1.076 & .196 & & \\
\hline & stan cywilny & -1.177 & 1.596 & -.089 & & \\
\hline & wykształcenie & 1.539 & 1.045 & .180 & & \\
\hline & \begin{tabular}{|l} 
poczucie własnej \\
skuteczności
\end{tabular} & -.530 & .126 & $-.506 * * *$ & & \\
\hline & $\begin{array}{l}\text { poziom niepełno- } \\
\text { sprawności }\end{array}$ & -.121 & .452 & -.033 & & \\
\hline
\end{tabular}

$* \mathrm{p}<.05 ; * * \mathrm{p}<.01 ; * * * \mathrm{p}<.001$

Źródło: badanie własne.

Szczegółowe analizy uwarunkowania oceny znaczenia choroby w kontekście wieku badanych pokazują, że wśród chorych z SMRR do 45. r.ż. poczucie własnej skuteczności jest statystycznie istotnie powiązane z oceną choroby jako zagrożenia $(\mathrm{p}<.01)$ i przeszkody $(\mathrm{p}<.001)-$ w taki sposób, że im niższe poczucie własnej skuteczności, tym częściej własna choroba jest ujmowana w tych kategoriach. Ponadto im niższe poczucie własnej skuteczności, tym bardziej negatywnymi treściami jest nasycone tak trudne wydarzenie życiowe, jak choroba $(\mathrm{p}<.001)$.

Wśród chorych w wieku powyżej 46 lat niższe poczucie własnej skuteczności wiąże się statystycznie istotnie z ujmowaniem choroby jako zagrożenia $(\mathrm{p}<.01)$ i przeszkody $(\mathrm{p}<.001)$. Tacy pacjenci oceniają swoją chorobę bardziej negatywnie $(\mathrm{p}<.01)$ aniżeli chorzy z wyższym poczuciem własnej skuteczności. $\mathrm{Ci}$ ostatni natomiast $-\mathrm{w}$ większym stopniu niż pacjenci z niskim poczuciem skuteczności traktują własną chorobę jako wartość $(\mathrm{p}<.05)$. Ponadto zaobserwowano, że wyższy poziom niepełnosprawności statystycznie istotnie $(\mathrm{p}<$ .001) wiąże się z częstszym ujmowaniem choroby jako przeszkody oraz że pozostawanie w związku małżeńskim/partnerskim koreluje dodatnio $(\mathrm{p}<.05) \mathrm{z}$ traktowaniem choroby jako znaczącego zakłócenia równowagi życiowej. Osoby pozostające w związku oceniają swoją chorobę bardziej negatywnie niż osoby stanu wolnego. 
Tabela 5. Ocena znaczenia własnej choroby wśród osób chorych na SMRR w wieku od 46. r.ż. $(\mathrm{N}=59)$ mierzona za pomocą Skali Oceny Własnej Choroby

\begin{tabular}{|c|c|c|c|c|c|c|}
\hline & Predyktory & B & $\begin{array}{c}\text { Bląd } \\
\text { standardowy } \\
\end{array}$ & $\boldsymbol{\beta}$ & Podsumowanie modelu & $\begin{array}{c}\text { Skorygowa- } \\
\text { ne } \mathbf{R}^{2}\end{array}$ \\
\hline \multirow{6}{*}{ 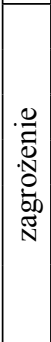 } & stała & 41.068 & 6.741 & & $F(5 ; 53)=2.808 ; p<.05$ & .135 \\
\hline & płeć & 3.015 & 2.408 & .171 & & \\
\hline & stan cywilny & 4.162 & 2.474 & .215 & & \\
\hline & wykształcenie & -3.254 & 2.409 & -.176 & & \\
\hline & \begin{tabular}{|l|}
$\begin{array}{l}\text { poczucie własnej } \\
\text { skuteczności }\end{array}$ \\
\end{tabular} & -.552 & .201 & $-.351 * *$ & & \\
\hline & \begin{tabular}{|l|}
$\begin{array}{l}\text { poziom niepełno- } \\
\text { sprawności }\end{array}$ \\
\end{tabular} & -.361 & .620 & -.075 & & \\
\hline \multirow{6}{*}{ 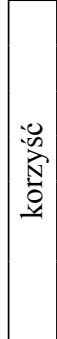 } & stała & 11.562 & 4.089 & & $F(5 ; 53)=2.324 ; p>.05$ & .102 \\
\hline & płeć & -2.866 & 1.460 & -.274 & & \\
\hline & stan cywilny & -1.515 & 1.500 & -.132 & & \\
\hline & wykształcenie & -1.186 & 1.461 & -.108 & & \\
\hline & \begin{tabular}{|l|}
$\begin{array}{l}\text { poczucie własnej } \\
\text { skuteczności }\end{array}$ \\
\end{tabular} & .229 & .122 & .244 & & \\
\hline & \begin{tabular}{|l|}
$\begin{array}{l}\text { poziom niepełno- } \\
\text { sprawności }\end{array}$ \\
\end{tabular} & .299 & .376 & .105 & & \\
\hline \multirow{6}{*}{ 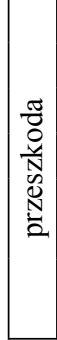 } & stała & 38.601 & 5.510 & & $F(5 ; 53)=6.040 ; p<.001$ & .303 \\
\hline & płeć & -1.102 & 1.968 & -.069 & & \\
\hline & stan cywilny & 2.016 & 2.022 & .115 & & \\
\hline & wykształcenie & -.236 & 1.969 & -.014 & & \\
\hline & \begin{tabular}{|l|}
$\begin{array}{l}\text { poczucie własnej } \\
\text { skuteczności }\end{array}$ \\
\end{tabular} & -.729 & .165 & $-.509 * * *$ & & \\
\hline & $\begin{array}{l}\text { poziom niepełno- } \\
\text { sprawności }\end{array}$ & 2.108 & .507 & $.483 * * *$ & & \\
\hline \multirow{6}{*}{ 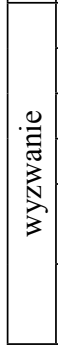 } & stała & 19.862 & 3.562 & & $F(5 ; 53)=1.349 ; p>.05$ & .029 \\
\hline & płeć & -2.654 & 1.273 & -.302 & & \\
\hline & stan cywilny & -.109 & 1.307 & -.011 & & \\
\hline & \begin{tabular}{|l|} 
wykształcenie \\
\end{tabular} & .465 & 1.273 & .050 & & \\
\hline & $\begin{array}{l}\text { poczucie własnej } \\
\text { skuteczności }\end{array}$ & .144 & .106 & .183 & & \\
\hline & $\begin{array}{l}\text { poziom niepełno- } \\
\text { sprawności }\end{array}$ & .064 & .328 & .027 & & \\
\hline \multirow{6}{*}{ 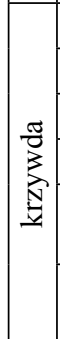 } & stała & 25.345 & 6.265 & & $F(5 ; 53)=1.764 ; p>.05$ & .062 \\
\hline & płeć & -1.861 & 2.238 & -.119 & & \\
\hline & stan cywilny & .625 & 2.299 & .036 & & \\
\hline & wykształcenie & -4.708 & 2.239 & -.285 & & \\
\hline & \begin{tabular}{|l}
$\begin{array}{l}\text { poczucie własnej } \\
\text { skuteczności }\end{array}$ \\
\end{tabular} & -.220 & .187 & -.157 & & \\
\hline & $\begin{array}{l}\text { poziom niepełno- } \\
\text { sprawności }\end{array}$ & .209 & .576 & .049 & & \\
\hline
\end{tabular}




\begin{tabular}{|c|c|c|c|c|c|c|}
\hline & Predyktory & B & $\begin{array}{c}\text { Błąd } \\
\text { standardowy }\end{array}$ & $\boldsymbol{\beta}$ & Podsumowanie modelu & $\begin{array}{l}\text { Skorygowa- } \\
\text { ne } R^{2}\end{array}$ \\
\hline \multirow{6}{*}{ 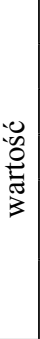 } & stała & 5.215 & 4.903 & & $F(5 ; 53)=1.549 ; p>.05$ & .045 \\
\hline & płeć & -.640 & 1.751 & -.053 & & \\
\hline & stan cywilny & .704 & 1.799 & .053 & & \\
\hline & wykształcenie & -.373 & 1.752 & -.029 & & \\
\hline & $\begin{array}{l}\text { poczucie własnej } \\
\text { skuteczności }\end{array}$ & .368 & .147 & $.338^{*}$ & & \\
\hline & $\begin{array}{l}\text { poziom niepełno- } \\
\text { sprawności }\end{array}$ & .075 & .451 & .023 & & \\
\hline \multirow{6}{*}{ 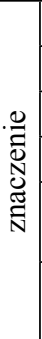 } & stała & 24.459 & 3.941 & & $F(5 ; 53)=3.328 ; p<.05$ & .167 \\
\hline & płeć & -.038 & 1.408 & -.004 & & \\
\hline & stan cywilny & 3.536 & 1.446 & $.307^{*}$ & & \\
\hline & wykształcenie & -.171 & 1.409 & -.016 & & \\
\hline & \begin{tabular}{|l}
$\begin{array}{l}\text { poczucie własnej } \\
\text { skuteczności }\end{array}$ \\
\end{tabular} & -.363 & .118 & $-.388 * *$ & & \\
\hline & $\begin{array}{l}\text { poziom niepełno- } \\
\text { sprawności }\end{array}$ & .305 & .362 & .107 & & \\
\hline
\end{tabular}

$* \mathrm{p}<.05 ; * * \mathrm{p}<.01 ; * * * \mathrm{p}<.001$

Źródło: badanie własne.

\section{DYSKUSJA}

Coraz częściej w literaturze naukowej zwraca się uwagę na znaczenie subiektywnej oceny choroby przewlekłej jako wyjątkowo silnego stresora $\mathrm{w}$ procesie emocjonalnego i behawioralnego przystosowania do trudnej sytuacji życiowej (Lazarus, Folkman, 1984; Taylor, 1995, za: Kossakowska, 2008). Istotnego znaczenia nabiera zatem to, czy choroba zostanie ujęta jako zagrożenie bądź strata, czy - bardziej konstruktywnie-jako wyzwanie (Lazarus, Folkman, 1984). Ponadto ta ocena zależy od posiadanych zasobów osobistych, m.in. od czynników psychospołecznych oraz od tak ważnej dyspozycji jak poczucie własnej skuteczności (Ford, Barrow, Stohl, 1996, za: Janowski i in., 2016; Juczyński, 1999; Lazarus, Folkman, 1984; Taylor, 1995, za: Kossakowska, 2008; Sęk, 2012). Z podanych powodów ta sama choroba może u jednych osób wywoływać dezorganizację życia, u innych zaś nie powodować jakichkolwiek zmian (Bishop, 2000; Falvo, 2005, za: Ziarko, 2014).

Rzadko natomiast rozpatrywano ocenę znaczenia choroby w kontekście okresu rozwojowego, a przecież badania pokazują, że osoby młode, w średnim wieku i starsze inaczej pojmują zdrowie (Malinowska, Dzwonkowska-Godula, Garncarek, Czarnecka, Brzezińska, 2016), odmiennie traktują objawy choroby, różnie radzą sobie $\mathrm{z}$ nią oraz przejawiają zindywidualizowane postawy wobec niej (Tobiasz-Adamczyk $i$ in., 2007). Przeprowadzone badanie wykazało, że starsi pacjenci z SMRR częściej postrzegają własną chorobę w kategoriach przeszkody i korzyści (należy zaznaczyć, że w tych analizach w zmienną wieku jest uwikłany stopień zaawansowania procesu chorobowego i poziom wykształcenia chorych (por. tab. 1 i informacje dot. wyniku na skali EDSS). Kolejne analizy ukazują szczegółowy związek wybranych zmiennych psychospołecznych z oceną znaczenia choroby w kontekście wieku osób z SM).

Specyfika SM powoduje, że wraz z wiekiem wzrasta świadomość destrukcyjnego charakteru choroby, a także utraty kontroli nad jej przebiegiem (Ross, Walker, MacLeod, 2004; Williams, Koocher, Adressing, 1998). Aktualne wyniki badań wskazują na to (Król, Koziarska, Rzepa, Szcześniak, Nowacki, 2017), że sami pacjenci postrzegają SM jako chorobę prowadzącą przede wszystkim do destrukcji fizycznej. Niesprawność powoduje, że codzienne, a nawet rutynowe czynności zaczynają przy- 
sparzać wiele trudu i stają się przeszkodami wymagającymi nieustannego przezwyciężania przez chorego człowieka (Bejer, Ziemba, 2015). To zmusza do zmiany sposobów dotychczasowego funkcjonowania, a jednocześnie wymaga znalezienia równowagi między pozostawaniem kimś niezależnym a coraz większą zależnością od innych ludzi (Steuden, Okła, 2007). Wraz z nasilaniem się niepełnosprawności i skarg na kondycję fizyczną obniża się zarówno ocena jakości życia, jak i skłonność do akceptacji przewlekłej choroby oraz słabnie zdolność radzenia sobie z wyzwaniami, jakie niesie (Humańska, Śnieg, Rezmerska, Haor, Głowacka, Felsmann, Ponczek, Kurowska, Pluta, Czarnecki, 2013; Kikuchi, Mifune, Niino, Kira, Kohriyama, Tanaka, Ochi, Nakane, Kikuchi, 2013; Król, Szcześniak, Koziarska, Rzepa, 2015; Lobentanz, Asenbaum, Vass, Sauter, Klösch, Kollegger, Kristoferitsch, Zeitlhofer, 2004; Łabuz-Roszak, Kubicka-Bączyk, Pierzchała, Horyniecki, Machowska-Mejchrzak, Augustyńska-Mutryn, Kosałka, Michalski, Pyszak, Wach, 2013; Miller, Dishon, 2006). Nie dziwi więc ustalenie, że dla starszych chorych, o wyższym poziomie niesprawności, czynnik ten ma istotne znaczenie w ocenie znaczenia własnej choroby.

Ponadto średni wiek życia wiąże się z opuszczeniem domu przez dorastające dzieci, a tym samym z koniecznością modyfikacji dotychczasowych zadań rodzicielskich i małżeńskich. Spełnienie nowych wymogów i oczekiwań może być utrudnione w związku z postępującą chorobą. Bernarda Bereza (2009) ustaliła, że wsparcie otrzymywane od dorosłych dzieci koreluje dodatnio z oceną choroby jako przeszkody i zagrożenia oraz zwiększa poczucie niepokoju, co jest spowodowane zakłóceniem dotychczasowej równowagi i zajmowanej pozycji w rodzinie.

Jak wspomniano, starsi chorzy częściej niż młodsi oceniają własną chorobę w kategoriach korzyści. Badania Kennetha I. Pakenhama (2005) wskazują, że korzyści związane z chorowaniem dotyczą w szczególności wzrostu osobistego i poprawy stosunków rodzinnych. Indywidualne wywiady $\mathrm{z}$ chorymi przeprowadzone przez Joannę Furmańską pokazują m.in., że starsi pacjenci uzyskują większą pomoc ze strony współmałżonka i dorosłych dzieci aniżeli młodsi pacjenci, a także mają zabezpieczenie finansowe w postaci renty. Wtórne korzyści być może wiążą się również z otrzymywaniem większej uwagi i zainteresowania, zwolnieniem z obowiązków i z podejmowania nowych ról, jak też z odstąpieniem od partnerstwa w relacjach społecznych na rzecz relacji asymetrycznych. Mimo że motywy odnajdywania tego typu korzyści mogą się wydać wątpliwe etycznie, to z perspektywy psychologii pozytywnej nie powinno się ich negować, a nawet powinno się zgłębić ich naturę i ocenić, na ile są to faktyczne korzyści, a na ile mechanizmy obronne (Kossakowska, Zielazny, 2013). Inne badania pokazują, że emocjonalne strategie radzenia sobie z przewlekłą chorobą są częściej wykorzystywane w początkowych fazach jej leczenia, związanych z nasileniem i nieznajomością objawów oraz z wyższym poziomem stresu (Eklund, MacDonald, 1999, za: Kossakowska, 2008), natomiast u osób długotrwale doświadczających skutków choroby mogą już dominować zadaniowe strategie radzenia sobie ze stresem (Pakenham, 1999; Warren, Warren, Cockerill, 1991), co umożliwia płynną adaptację do sytuacji choroby.

Analiza związku czynników psychospołecznych z oceną znaczenia choroby w zależności od wieku pacjentów z SMRR wykazała, że wśród chorych do 45. r.ż. wartość różnicującą ma poczucie własnej skuteczności, natomiast wśród osób powyżej 46. r.ż. taką rolę odgrywają oprócz poczucia własnej skuteczności także stan cywilny i poziom niepełnosprawności.

Warto zauważyć, że niektóre badania wskazują na wiek i płeć jako czynniki różnicujące ocenę znaczenia własnej choroby (Janowski, 2006). Jednocześnie warto podkreślić, że w innym badaniu, przeprowadzonym m.in. przez tego autora, wykazano statystycznie istotne różnice wyłącznie pomiędzy skrajnymi grupami, tj. pomiędzy pacjentami w wieku do 30. i powyżej 70. r.ż. oraz wyłącznie w ramach kategorii zagrożenia (Janowski i in., 2009). Dlatego we wnioskach z tych badań zasugerowano, że więcej czynników psychospołecznych może modyfikować ocenę choroby. To prawda, że osoby w okresie średniej i późnej dorosłości odgrywają wiele ról społecznych, dokonują nie- 
łatwych wyborów i wzbogacają swe doświadczenie życiowe, a do realizacji kolejnych zadań rozwojowych wykorzystują stale tak kluczową dyspozycję, jak poczucie własnej skuteczności. Osoby młodsze dopiero wkraczają w dorosłość i zaczynają osiągać pierwsze cele życiowe oraz poznawać reguły funkcjonowania w określonych rolach społeczno-zawodowych. Być może dlatego w tej grupie wiekowej czynnik pozostawania w związku partnerskim/małżeńskim nie stanowi o istotnej zmienności. Ponadto początek chorowania „rządzi się” swoimi prawami i wymaga koncentracji na chorobie jako na szczególnie ważnym wydarzeniu życiowym, więc większe znaczenie dla jej oceny mają czynniki kliniczne, związane przede wszystkim z procesem leczenia.

\section{PODSUMOWANIE}

Istotnym aspektem stwardnienia rozsianego jest to, iż ta nieuleczalna i przewlekła choroba dotyka osoby w młodym wieku, znajdujące się na ważnym etapie rozwoju osobistego, zawodowego i rodzinnego. Postępująca niepełnosprawność towarzyszy chorym przez wiele lat, odciskając swe piętno na wszystkich obszarach funkcjonowania, a zwłaszcza na odgrywanych rolach społecznych i zawodowych. Status choroby przewlekłej wymaga zatem ciągłego dostosowywania się do zmian wynikających z nieuchronnych postępów choroby.

Wnioski płynące z przeprowadzonego badania poszerzają wiedzę teoretyczną na temat unikalnych i typowych uwarunkowań psychospołecznego funkcjonowania chorych na stwardnienie rozsiane, wskazując na zmienną wieku jako istotny element oceny znaczenia choroby. Szczegółowa analiza empiryczna pozwoliła na wskazanie czynników, które, w zależności od wieku badanych, nabierają szczególnego znaczenia w powiązaniu $\mathrm{z}$ wybranymi kategoriami psychologicznymi. Uzyskane wyniki mogą być przydatne w pracy interdyscyplinarnych zespołów sprawujących opiekę nad tą populacją pacjentów, dając podstawę do projektowania i wdrażania odpowiednich oddziaływań profilaktycznych, psychoedukacyjnych i terapeutycznych, odwołujących się do ocen poznawczych chorych. Chodzi o wskazanie na wartość aktywnego udziału w procesie leczenia, a także rolę zasobu osobistego - poczucia własnej skuteczności w tym procesie.

\section{PRZYPISY}

Mężczyźni zakodowani jako „0”, a kobiety jako „1”.

Kodem „0” oznaczono osoby z wykształceniem zawodowym i średnim, a kodem „1” oznaczono osoby z wykształceniem licencjackim i wyższym.

Osoby samotne oznaczono kodem „0”, a osoby pozostające w związku oznaczono kodem „,".

\section{BIBLIOGRAFIA}

Baum S.K., Stewart R.B. Jr. (1990), Sources of meaning trough the life-span. Psychological Reports, 67, 3-14. Bejer A., Ziemba J. (2015), Jakość życia chorych na stwardnienie rozsiane a stopień niepełnosprawności ruchowej - doniesienie wstępne. Medycyna Ogólna i Nauki o Zdrowiu, 21(4), 402-407.

Bereza B. (2009), Doświadczanie własnej choroby przez pacjentów dializowanych. Lublin: Wydawnictwo Towarzystwa Naukowego Katolickiego Uniwersytetu Lubelskiego.

Bishop G. (2000), Psychologia zdrowia. Wrocław: Astrum.

Brzezińska A. (2005), Psychologiczne portrety człowieka. Praktyczna psychologia rozwojowa. Gdańsk: Gdańskie Wydawnictwo Psychologiczne.

Brzezińska A., Trempała J. (2000), Wprowadzenie do psychologii rozwoju. W: J. Strelau (red.), Psychologia. Podręcznik akademicki, t. 1, 229-294. Gdańsk: Gdańskie Wydawnictwo Psychologiczne.

Harwas-Napierała B., Trempała J. (red.) (2007), Psychologia rozwoju człowieka. Charakterystyka okresów zycia czlowieka, t. 2. Warszawa: Wydawnictwo Naukowe PWN. 
Heszen I., Sęk H. (2007), Psychologia zdrowia. Warszawa: Wydawnictwo Naukowe PWN.

Heszen-Klemens I. (1979), Poznawcze uwarunkowania zachowania się wobec wtasnej choroby. Wrocław: Zakład Narodowy im. Ossolińskich Wydawnictwo Polskiej Akademii Nauk.

Heszen-Klemens I. (1983), Psychologia medyczna. Główne kierunki badań. Katowice: Uniwersytet Śląski.

Humańska M.A., Śnieg P., Rezmerska L., Haor B., Głowacka M., Felsmann M., Ponczek D., Kurowska K., Pluta A., Czarnecki D. (2013), Jakość życia a sprawność funkcjonalna chorych na stwardnienie rozsiane. Pielegniarstwo Neurologiczne i Neurochirurgiczne, 2(5), 188-194.

Janowski K. (2006), Osobowościowe uwarunkowania radzenia sobie ze stresem tuszczycy. Lublin: POLIHYMNIA.

Janowski K., Steuden S., Kuryłowicz J., Nieśpiałowska-Steuden M. (2009), The Disease-related appraisals scale: a tool to measure subjective perception of the disease situation. W: K. Janowski, S. Steuden (eds.), Biopsychosocial Aspects of Health and Disease, 108-125. Lublin: CPPP Scientific Press.

Janowski, K., Tatala, M., Jedynak, T., Księżpolska, A., Głowacka, B. (2016). Wsparcie społeczne a ocena własnej choroby, nasilenie objawów depresyjnych i akceptacja życia z chorobą u kobiet po mastektomii. Polskie Forum Psychologiczne, 21(2), 188-205.

Juczyński, Z. (1999). Narzędzia pomiaru w psychologii zdrowia. Przegląd Psychologiczny, 42(4), 43-56.

Juczyński Z. (2001), Skala uogólnionej własnej skuteczności - GSES. W: Z. Juczyński (red.), Narzędzia pomiaru w promocji i psychologii zdrowia, 93-98. Warszawa: Pracownia Testów Psychologicznych Polskiego Towarzystwa Psychologicznego.

Kielar-Turska M. (2000), Rozwój człowieka w pełnym cyklu życia. W: J. Strelau (red.), Psychologia. Podręcznik akademicki, t. 1, 295-332. Gdańsk: Gdańskie Wydawnictwo Psychologiczne.

Kikuchi H., Mifune N., Niino M., Kira J., Kohriyama T., Tanaka M., Ochi H., Nakane S., Kikuchi S. (2013), Structural equation modeling of factors contributing to quality of life in Japanese patients with multiple sclerosis. BMC Neurology, 13(10), 1-9.

Kossakowska M. (2008), Strategie radzenia sobie z chorobą przewlekłą w stwardnieniu rozsianym. Postępy Psychiatrii i Neurologii, 17(1), 15-21.

Kossakowska M., Zemła-Sieradzka L. (2011), Wybrane pozytywne aspekty zmagania się z przewlekłą chorobą u osób chorych na stwardnienie rozsiane. Postępy Psychiatrii i Neurologii, 20(4), 259-267.

Kossakowska M., Zielazny P. (2013), Obraz choroby i korzyści psychospołeczne u osób zakażonych wirusem HIV i chorych na AIDS. Postepy Psychiatrii i Neurologii, 22(3), 177-185.

Król J., Koziarska D., Rzepa T., Szcześniak M., Nowacki P. (2017), Percepcja własnej choroby przez osoby $\mathrm{z}$ rzutowo-remisyjną postacią stwardnienia rozsianego (SMRR) - doniesienie wstępne. Postepy Psychiatrii i Neurologii, 1, 24-35.

Król, J., Szcześniak, M., Koziarska, D., Rzepa, T. (2015). Akceptacja choroby i postrzeganie czasu u osób leczonych immunomodulacyjnie z rzutowo-remisyjną postacią stwardnienia rozsianego (RR-SM). Psychiatria Polska, 49(5), 911-920.

Kurtzke F.F. (1983), Rating neurologic impairment in multiple sclerosis: An expanded disability status scale (EDSS). Neurology, 33, 1444-1452.

Lazarus R., Folkman S. (1984), Stress, Appraisal and Coping. New York: Springer.

Leventhal H., Idler E.L., Leventhal E.A. (1999), The impact of chronic illness on the self-system. W: R.J. Cotrada, R.D. Ashmore (eds.), Self, Social Identity and Physical Health, 185. New York: Interdisciplinary Explorations, Oxford University Press.

Levinson D.J. (1986), Aconception of adult development. American Psychologist, 4(1), 3-13.

Lobentanz I.S., Asenbaum S., Vass K., Sauter C., Klösch G., Kollegger H., Kristoferitsch W., Zeitlhofer J. (2004), Factors influencing quality of life in multiple sclerosis patients: disability, depressive mood, fatigue and sleep quality. Acta Neurologica Scandinavica, 110, 6-13.

Łabuz-Roszak B., Kubicka-Bączyk K., Pierzchała K., Horyniecki M., Machowska-Mejchrzak A., Augustyńska-Mutryn D., Kosałka K., Michalski K., Pyszak D., Wach J. (2013), Jakość życia chorych na stwardnienie rozsiane - związek z cechami klinicznymi choroby, zespołem zmęczenia i objawami depresyjnymi. Psychiatria Polska, 47(3), 433-442.

Maciejak Z., Wawrzyniak S. (2013), Objawy kliniczne i przebieg choroby. W: J. Losy (red.), Stwardnienie rozsiane, 59-74. Lublin: Wydawnictwo Czelej. 
Malinowska E., Dzwonkowska-Godula K., Garncarek E., Czarnecka J., Brzezińska J. (2016), Kulturowe uwarunkowania postaw kobiet $i$ mężczyzn $w$ różnym wieku wobec swego wygladu i zdrowia. Łódź: Wydawnictwo Uniwersytetu Łódzkiego.

Miller A., Dishon S. (2006), Health-related quality of life in multiple sclerosis: the impact of disability, gender and employment status. Quality of Life Research, 15, 259-271.

Pakenham K. (1999), Adjustment to multiple sclerosis: application of stress and coping model. Health Psychology, 18(40), 383-392.

Pakenham K.I. (2005), Benefitfinding in multiple sclerosis and associations with positive and negative outcomes. Health Psychology, 24 (2), 123-132.

Ross S., Walker A., MacLeod M.J. (2004), Patient compliance in hypertension: role of illness perceptions and treatment beliefs. Journal of Human Hypertension, 18, 607-613.

Schwarzer R. (1993), Measurement of perceived self-efficacy. Psychometric scales for cross-cultural research. Berlin: Freie Universität Berlin.

Selmaj K. (2005), Stwardnienie rozsiane - kryteria diagnostyczne i naturalny przebieg choroby. Polski Przegląd Neurologiczny, 1(3), 99-105.

Selmaj K. (2006), Stwardnienie rozsiane. Poznań: Termedia.

Sęk, H. (2012). Rola wsparcia życiowego w sytuacjach stresu życiowego. W: H. Sęk, R. Cieślak (red.), Wsparcie spoleczne, stres i zdrowie, 49-67. Warszawa: Wydawnictwo Naukowe PWN.

Steuden S., Okła W. (2007), Jakość życia w chorobie. Lublin: Wydawnictwo KUL.

Strelau J. (1996), Temperament a stres: Temperament jako czynnik moderujący stresory, stan i skutki stresu oraz radzenie sobie ze stresem. W: I. Heszen-Niejodek, Z. Ratajczak (red.), Czlowiek w sytuacji stresu, 88-132. Katowice: Wydawnictwo Uniwersytetu Śląskiego.

Tobiasz-Adamczyk B., Zapała J., Zawisza K., Bronicki T. (2007), Wiek a zachowania w chorobie wśród osób z nowotworami głowy i szyi. Gerontologia Polska, 15(3), 82-89.

Warren S., Warren K.G., Cockerill R. (1991), Emotional stress and coping in multiple sclerosis exacerbations. Journal of Psychosomatic Research, 35(1), 37-47.

Watkins K.W., Connell C.M., Fitzgerald J.T., Klem L., Hickey T., Ingersoll-Dayton B. (2000), Effects of adults' self-regulation on quality of life outcomes. Diabetes Care, 23, 1511-1515.

Wender M., Liberski P.P. (2013), Neuropatologia. W: J. Losy (red.), Stwardnienie rozsiane, 29-44. Lublin: Wydawnictwo Czelej.

Williams J., Koocher G.P. (1998), Adressing loss of control in chronic illness: Theory and practice. Psychotherapy, 35(3), 325-335.

Ziarko M. (2014), Zmaganie się ze stresem choroby przewlektej. Poznań: Wydawnictwo Naukowe Wydziału Nauk Społecznych Uniwersytetu im. Adama Mickiewicza w Poznaniu. 